\title{
Pentastomid infection in Philodryas nattereri Steindachner, 1870 and Oxybelis aeneus (Wagler, 1824) (Squamata: Colubridae) in a caatinga of northeastern Brazil
}

\author{
Almeida, WO. ${ }^{\mathrm{a} *}$, Guedes, TB. ${ }^{\mathrm{b}}$, Freire, EMX. ${ }^{\mathrm{b}}$ and Vasconcellos, $A .^{\mathrm{b}}$ \\ ${ }^{a}$ Departamento de Ciências Físicas e Biológicas, Universidade Regional do Cariri, \\ R. Cel. Antônio Luiz, 1161, CEP 63105-000, Crato, CE, Brasil \\ 'Departamento de Botânica, Centro de Biociências, Ecologia e Zoologia, \\ Universidade Federal do Rio Grande do Norte - UFRN, Natal, RN, Brasil \\ *e-mail: walmeida@urca.br
}

Received May 5, 2006 - Accepted July 4, 2006 - Distributed February 29, 2008

(With 2 figures)

\begin{abstract}
The relationship between pentastomids and two Colubridae species, Phillodryas nattereri Steindachner, 1870 and Oxybelis aeneus (Wagler, 1824), were investigated in the federal government's reserve Estação Ecológica do Seridó (ESEC, Seridó) situated at lat $6^{\circ} 35^{\prime}-40^{\prime} \mathrm{S}$ and long $37^{\circ} 15^{\prime}-20 \mathrm{~W}$ in the municipality of Serra Negra do Norte, state of Rio Grande do Norte, Northeast Brazil and run by IBAMA (the Brazilian Institute for the Environment and Natural Resources). Throughout 2005, 26 specimens of snakes, 13 of $P$. nattereri and 13 of $O$. aeneus were collected. After anatomical dissection and laboratorial examination of the snakes' respiratory tracts, $P$. natterer $i$ was found to be parasitized by two species of pentastomids: Cephalobaena tetrapoda Heymons, 1922 with a prevalence of $30.8 \%$ and a mean intensity of infection of $51.5 \pm$ 32.7 (range 3-147), and Raillietiella furcocerca (Diesing, 1863) which had a prevalence of $7.7 \%$ and a mean intensity of infection of 1.0. Only one female of O. aeneus was found to be infected by $C$. tetrapoda, with a prevalence of $7.7 \%$ and mean intensity of infection of 2.0. There was no significant relationship between size of snout-vent length (SVL) and intensity of infection in the specimens investigated here. The two individuals of $P$. nattereri infected by more than 40 specimens of pentastomids had their lungs completely infected including the pulmonary peritoneum and trachea. It is noteworthy that the hosts had their lung tissues partially destroyed with apparent haemorrhage, and the trabecular structure of their lungs was also destroyed. The contrasting rates of infection estimated here may be related to differences in foraging strategies, in diet, and habitat selection carried out by individuals of $P$. nattereri and $O$. aeneus.
\end{abstract}

Keywords: Endoparasites, Cephalobaena, Raillietiella, neotropical region.

\section{Infecção por pentastomídeos em Philodryas nattereri Steindachner, 1870 e Oxybelis aeneus (Wagler, 1824) (Squamata: Colubridae) em uma Caatinga do nordeste do Brasil}

\section{Resumo}

As relações entre pentastomídeos e duas espécies de Colubridae, Phillodryas nattereri Steindachner, 1870 e Oxybelis aeneus (Wagler, 1824), foram investigadas na Estação Ecológica do Seridó (ESEC-Seridó) situada em 6³5' - 40’S e 37²15' - 20'W no município de Serra Negra do Norte, Estado do Rio Grande do Norte, Nordeste do Brasil, mantida pelo IBAMA (Instituto Brasileiro do Meio Ambiente e dos Recursos Naturais Renováveis). Ao longo de 2005 foram coletados 26 espécimes de serpentes, sendo 13 de $P$. nattereri e 13 de O. aeneus. Depois da dissecação dos espécimes e exame em laboratório do trato respiratório, foram encontradas duas espécies de pentastomídeos parasitando $P$. nattereri: Cephalobaena tetrapoda Heymons, 1922 com prevalência 30.8\%, intensidade média de infecção $51.5 \pm 32.7$ (amplitude de 3-147) e Raillietiella furcocerca (Diesing, 1863) com prevalência 7.7\% e intensidade média de infecção 1.0. Apenas uma fêmea de $O$. aeneus estava infectada por $C$. tetrapoda com prevalência $7.7 \%$ e intensidade de infecção 2.0. Não houve relação significativa entre o comprimento rostro-anal (SVL) e a intensidade de infecção nos espécimes coletados. Os dois indivíduos de $P$. nattereri com infecção por pentastomídeos em número superior a 40 tinham seus pulmões completamente infectados por esses parasitas, incluindo a traquéia e peritônio pulmonar. Esses indivíduos possuíam seus pulmões gradualmente destruídos, hemorragias aparentes e partes da estrutura trabecular dos pulmões destruída. As taxas de infecção contrastantes estimadas aqui podem estar relacionadas com as diferenças de estratégias de forrageamento, dieta e seleção de habitats por $P$. nattereri e $O$. aeneus.

Palavras-chave: Endoparasitas, Cephalobaena, Raillietiella, região neotropical. 


\section{Introduction}

Pentastomids are pulmonary parasites of vertebrates that act as population regulators (Riley, 1986). Cases of acute infections with serious pulmonary lesions, reduction of egg production, and increased mortality have been reported in lizard communities (Riley, 1986; Pence and Selcer, 1988; Zhang et al., 1988, Riley et al., 1991). However, such consequences have not been investigated in snakes, mainly in the South America ecosystems.

In Brazil, only four species of pentastomids have been reported until now, as snake parasites: Cephalobaena tetrapoda Heymons, 1922; Kiricephalus coarctatus (Diesing, 1850); Porocephalus crotali (Humboldt, 1808) and Raillietiella furcocerca (Diesing, 1863). These species may be considered as generalists because their hosts belong to different snake families, genera, and species, whose diets vary from arthropods to vertebrates (Sambon, 1922; Heymons, 1935; Motta, 1963a, 1963b; Rego, 1981, 1983, 1984; Almeida and Christoffersen, 2002; Almeida et al., 2006, 2007).

Most of the above-mentioned studies have only reported the occurrence of pentastomids, except for the ones carried out by Almeida et al. (2006, 2007) who estimated for the first time pentastomids infecting snakes of the family Colubridae Liophis lineatus (Linnaeus, 1758), Philodryas nattereri Steindachner, 1870, and Elapidae Micrurus ibiboboca (Merrem, 1820), inhabiting the ecosystems of the semi-arid region of Ceará state, northeastern Brazil. Almeida et al. (2006, 2007) also confirmed C. tetrapoda as a generalist parasite of the colubrids $L$. lineatus and $P$. nattereri that feed on small vertebrates, which are likely to be intermediate hosts of pentastomids. It is quite relevant, as reported by Almeida et al. (2007) that the occurrence of $R$. furcocerca parasitizing
P. nattereri, indicating a prevalence and mean intensity of infection similar to the ones estimated by the authors in the case of $C$. tetrapoda within the same collection area, therefore confirms that different species of pentastomids share the same host. Almeida et al. (2006, 2007) emphasized the importance of further studies in other regions of Brazil, in order to research rates and patterns of infection of these parasites in South America ecosystems.

In the present study, the rates of infection evaluated in snakes from the microregion of Serido, in the state of Rio Grande do Norte are compared with those obtained from snakes from the microregion of Cariri, in the state of Ceará, both regions located in northeastern Brazil. The aim here was to search for similarities and differences with respect to: i) composition of pentastomid fauna, ii) patterns of infection (prevalence and intensity), iii) probable diseases these parasites cause to their hosts, and iv) the relationship between infection, sex, and body size of the host.

\section{Material and Methods}

The snakes were captured throughout 2005, using standard herpetological methods such as active patterned collection (Auricchio and Salomão, 2002) in the federal government's reserve Estação Ecológica do Seridó (ESEC, Seridó) situated at lat $6^{\circ} 35^{\prime}-40^{\prime} \mathrm{S}$ and long $37^{\circ} 15^{\prime}-20 \mathrm{~W}$ in the municipality of Serra Negra do Norte, state of Rio Grande do Norte, Northeast Brazil and run by IBAMA (the Brazilian Institute for the Environment and Natural Resources) (Figure 1). The region is characterized by a hot, semi-arid climate, with precipitation between 400 and $700 \mathrm{~mm} /$ year (average $497 \mathrm{~mm} /$ year) occurring predominantly from March to May. The average air temperature is from 28 to $30^{\circ} \mathrm{C}$ and average air

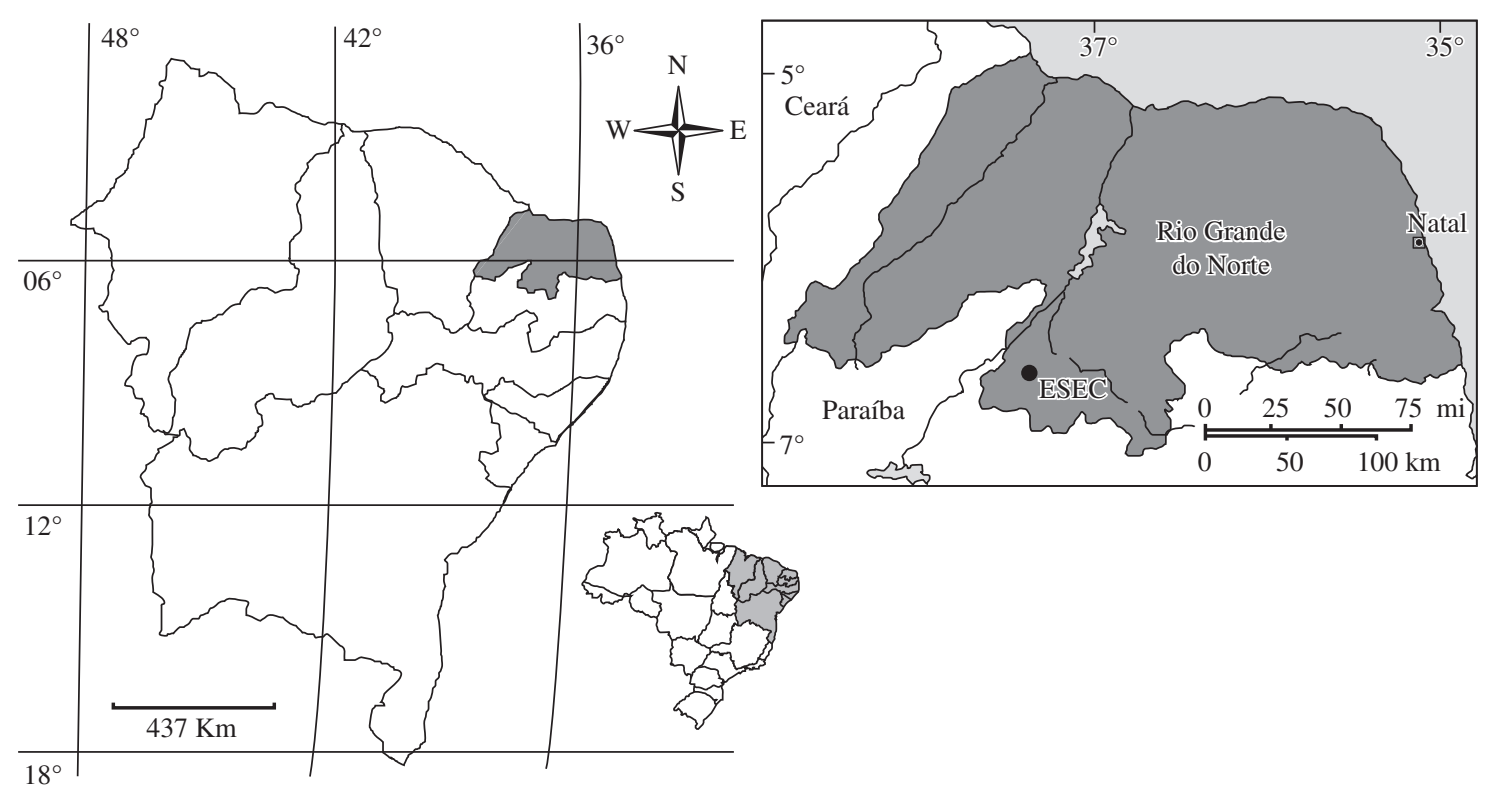

Figure 1. Location of the study area in Northeast Brazil. The federal government's reserve Estação Ecológica do Seridó (ESEC, Seridó), State of Rio Grande do Norte, Northeast Brazil, is indicated by the black dot. 
humidity is between 30 and $50 \%$ in the dry season. The vegetation is characterized as hyperxerophile Caatinga, consisting of deciduous xerophytic bushes and trees of up to $8-10 \mathrm{~m}$ height, under which a herbaceous layer is well developed, at least during the rainy season (VarelaFreire, 1995; 2002).

Upon collection, the snakes were frozen-euthanized and their snout-vent length (SVL) was measured with a ruler (to the nearest $1 \mathrm{~mm}$ ). The snakes were fixed in formalin $10 \%$ and preserved in ethanol $70 \%$. They were subsequently identified according to Vanzolini et al. (1980). After preservation treatment, they were housed in the Herpetological Collection of the Departamento de Botânica, Ecologia e Zoologia (CHBEZ) of the Universidade Federal do Rio Grande do Norte, and numbered as: CHBEZ 628, 1041, 1084, 1102, 1099-103, 1126-129, 1181, 1216, 1217, 1231, 1238, 1239, 1240, 1246-1249, 1311, 1313, 1314.

The respiratory tracts of the snakes were removed and the search for pentastomids was performed under a stereomicroscope. The pentastomids that were found were cleared in Hoyer's medium, temporarily slidemounted and preserved in ethanol $70 \%$. Identification was based on the dimensions of the hooks and male copulatory spicules (see Rego, 1983; 1984; Ali et al., 1984a; 1984b; 1985). During the identification of the individuals we also compared the specimens with material from the Helminthological Collection of the Instituto Oswaldo Cruz (CHIOC): C. tetrapoda (CHIOC 29185a-d, 29190a-1), R. furcocerca (CHIOC 31899a-c); and with material from the Coleção Zoológica da Universidade Regional do Cariri (LZ-URCA): C. tetrapoda (LZ-URCA 0043-0044; 0157-167) and R. furcocerca (LZ-URCA 168-170a-e).

The eco-parasitological terms used in this study followed the recommendations of Bush et al. (1997). The proportion of infected individuals was compared between sexes for $P$. nattereri using the Z-test for proportions (Zar, 1999).

\section{Results}

A total of 26 specimens of snakes were collected during the study period, 13 being Philodryas nattereri and 13 Oxybelis aeneus. The parasite species found in $P$. nattereri were Cephalobaena tetrapoda and Raillietiella furcocerca. In $O$. aeneus we only found $C$. tetrapoda, which represents a new host record for this pentastomid.

Of the 26 snakes collected, six $(23.1 \%)$ were infected with pentastomids. They were adults, as we noticed the uterus of the females full of eggs and their simple hooks with no chitinous accessories, which differentiates them from nymphs with their double hooks and chitinous accessories (Riley, 1986).

Of the 13 specimens of Philodryas nattereri we collected, $38.5 \%(5 / 13)$ were infected with pentastomids, being $C$. tetrapoda the most frequent species, representing a prevalence of $30.8 \%(4 / 13)$ and the highest mean of intensity of infection (51.5 \pm 32.7 ; range of 3-147). The two individuals of $P$. nattereri infected by more than 40 specimens of pentastomids had their lungs completely infected with these parasites including the pulmonary peritoneum and trachea. It is noteworthy that the hosts had their lung tissues partially destroyed with apparent haemorrhage, and the trabecular structure of their lungs was also destroyed (Figure 2). Raillietiella furcocerca was another species of pentastomid that we found parasitizing only one specimen of $P$. nattereri (prevalence $7.7 \%$ ) with a very low mean intensity of infection (1.0). We also observed only one specimen of O. aeneus infected with C. tetrapoda (prevalence $7.7 \%$ ) with a fairly low mean intensity of infection (2.0).

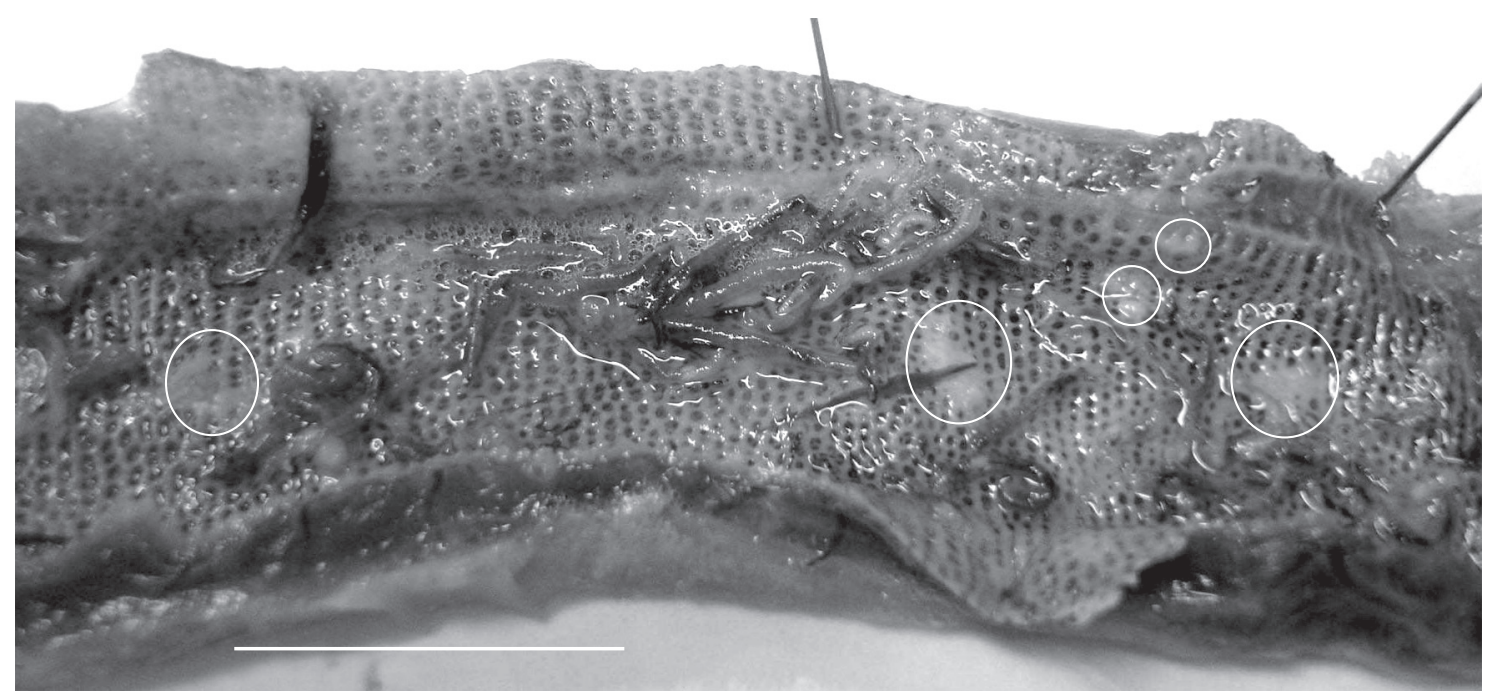

Figure 2. Opened lung of a specimen of Philodryas nattereri, the snake with the highest intensity of infection by the pentastomid Cephalobaena tetrapoda (147 individuals). The circles indicate points of destruction of pulmonary tissue. Bar $=3 \mathrm{~cm}$. 
The proportion of infected individuals was not different between males (1/7) and females (4/6) of $P$. nattereri $(\mathrm{Z}=1.21 ; \mathrm{P}=0.173)$. The snout-vent length had no significant variation among males (mean SVL $=82.47 \pm 15.04 \mathrm{~cm}$ ) and females (mean $\mathrm{SVL}=93.28 \pm 20.56)(\mathrm{t}=1.09 ; \mathrm{df}=11 ; \mathrm{P}=0.29)$. There was not any SVL variation among host individuals (mean SVL $=88.58 \pm 28.79 \mathrm{~cm}$ ) nor among non-host individuals (mean $\mathrm{SVL}=8.65 \mathrm{~cm})(\mathrm{t}=0.17$; $\mathrm{df}=11$; $\mathrm{P}=0.86)$.

\section{Discussion}

The rates of infection of Micrurus ibiboboca, Liophis lineatus and P. nattereri obtained by Almeida et al. (2006, 2007) were compared in this study, since they were snakes parasitized by pentastomids, in the microregion of Cariri, in the semi-arid northeastern Brazil. In both investigations (Almeida et al., 2006, 2007) and in the present study no difference of rates of infection between males and females was found nor any difference of size between infected and non-infected snakes. The pentastomid species ( $C$. tetrapoda and $R$. furcocerca) parasitizing $P$. nattereri in the microregion of Cariri (Ceará State) (Almeida et al., 2007) are the same species we detected in hosts thriving at the ESEC in the microregion of Seridó (Rio Grande do Norte state).

According to Almeida et al. (2007) a higher prevalence of $C$. tetrapoda in P. nattereri $(36.4 \%$ 4/11) was detected than in those results of Almeida et al. (2006) to L. lineatus $(16.7 \% 1 / 6)$, still both hosts presented similar values of mean intensity of infection ( $P$. nattereri $1.5 \pm 0.28$ and L. lineatus 2.0). However, differently from the population of L. lineatus in Almeida et al. (2006), P. nattereri's population was parasitized simultaneously by another pentastomid: $R$. furcocerca, presenting a prevalence of $27.3 \%$ (3/11) and mean intensity of infection of $2.3 \pm 1.32(1-5)$, which were similar to the values obtained from $C$. tetrapoda (Almeida et al., 2007). These results indicate that the generalist pentastomid species share the same host with no predominance of either. Otherwise, the investigation performed on Micrurus ibiboboca (Elapidae) in the same area of the $P$. nattereri's population, Almeida et al. (2007) reported for elapid a prevalence of $25 \%$ (1/4), a value similar to that of the infected P. nattereri. However, the pentastomid observed was probably a new species of Raillietiella and the mean intensity of infection was also different (1.0). Such similarities and differences, as observed by Almeida et al. (2007) result from differing forage and dietary habits of the studied snakes. Philodryas nattereri are free-ranging snakes that prey on small vertebrates, whereas $M$. ibiboboca is a fossorial and ophiphagous species (Vanzolini et al., 1980; Martins and Oliveira, 1999; Hartmann and Marques, 2005).

In the present study the prevalence of infection in P. nattereri and C. tetrapoda are similar (30.8\%, 4/13) while it is low for $R$. furcocerca $(7.7 \% 1 / 13)$. Such results are even more relevant when the values of mean inten- sity of infection are compared; for example C. tetrapoda infected strongly the hosts at the ESEC, Seridó (mean $51.5 \pm 32.7$; range $3-147$ ), causing serious damage to $P$. nattereri's lungs (Figure 2). Raillietiella furcocerca, however, was found parasitizing only one specimen of $P$. nattereri $(7.7 \%)$ with a very low mean intensity of infection (1.0). We do not have any explanation at the moment for this observation.

Oxybelis aeneus and Philodryas nattereri live in sympatry and feed on similar small vertebrates (Vanzolini et al., 1980; Martins and Oliveira, 1999; Hartmann and Marques, 2005). However, as C. tetrapoda parasitizing O. aeneus at the ESEC, Seridó, presented low prevalence $(7.7 \%, 1 / 13)$ and low mean of intensity of infection (2.0), this may have been the result of habit differences, since these snakes are predominantly arboreal species. Hence, phyllogenetic and ecological factors should be intimately related to patterns of infection determined by the pentastomids in the snakes studied here and by Almeida et al. (2006, 2007). Environmental or anthropic interferences probably must have a significant influence on the rates of pentastomid infection in snakes, leading us to agree with Marcogliese (2004) with respect to the need for associating all ecological studies on parasites and hosts. This would contribute towards better identification and better knowledge that would be useful for management and conservation plans, mainly in neotropical regions, where such kinds of information are still scarce.

Acknowledgments - We thank Dr Dely Noronha, curator of the Helminthological Collection of the Instituto Oswaldo Cruz, for the loan of pentastomid specimens. To FUNCAP - the Fundação Cearense de Apoio ao Desenvolvimento Científico e Tecnológico (Ref. 943/03 - Edital 003/03) for the research grant and a scholarship to Suzana Gomes Lopes. To the Conselho Nacional de Desenvolvimento Científico e Tecnológico (CNPq) for the research grant received through the Programa Ecológico de Longa Duração (PELD). To the Fundação Coordenação de Aperfeiçoamento de Pessoal de Nível Superior (CAPES) for the scholarship to Thais Barreto Guedes da Costa. Our thanks are also due to IBAMA (the Brazilian Institute for the Environment and Natural Resources) for issuing permission to collect samples from their protection areas (processos 02021.000075/20067and 080/04 - RAN/ IBAMA 02007.001009/04-73); to Dr Breno Grisi for his suggestions and the English version of the manuscript; we also thank the anonymous reviewer for the valuable suggestions and comments on the manuscript, and to Prof. Dr Jörn Seemann (URCA) for revising the English version of the text.

\section{References}

ALI, JH., RILEY, J. and SELF, JT., 1984a. A revision of the taxonomy of pentastomid parasites (genus Raillietiella Sambon, 1910) from American snakes and amphisbaenians. Syst. Parasitol., vol. 6, p. 87-97.

-, 1984b. Further observations of blunt-hooked raillietiellids (Pentastomida: Cephalobaenida) from lizards with descriptions of three new species. Syst. Parasitol., vol. 6, p. 147-160.

-, 1985. A review of the taxonomy and systematics of the pentastomids genus Raillietiella Sambon, 1910 with a description of a new species. Syst. Parasitol., vol. 7, p. 111-123. 
ALMEIDA, WO. and CHRISTOFFERSEN, ML., 2002. Pentastomida, p. 187-202. In MORRONE, J. and LLORENTEBOUSQUETS, J. (eds.), Biodiversidad, Taxonomía y Biogeografía de Artrópodos de México: Hacia una síntesis de su conocimiento, vol. 3. Universidad Nacional Autónoma de México, México, 690 p.

ALMEIDA, WO., BRITO, SV., FERREIRA, FS. and CHRISTOFFERSEN ML., 2006. First record of Cephalobaena tetrapoda (Pentastomida: Cephalobaenidae) as a parasite on Liophis lineatus (Ophidia: Colubridae) in Northeast Brazil. Braz. J. Biol., vol. 66, no. 1a, p. 559-564.

ALMEIDA, WO., VASCONCELLOS, A., LOPES, SG. and FREIRE, EMX., 2007. Prevalence and intensity of pentastomid infection in two species of snakes from Northeastern Brazil. Braz. J. Biol.,vol. 67, no. 4, p. 759-763.

AURICCHIO, P. and SALOMÃO, MG. (Orgs.), 2002. Técnicas de coleta e preparação de vertebrados para fins científicos $e$ didáticos. Instituto Pau Brasil de História Natural, São Paulo, $348 \mathrm{p}$.

BUSH, AO., LAFFERTY, KD., LOTZ, JM. and SHOSTAK, AW., 1997. Parasitology meets ecology in its own terms: Margulis et al. revisited. J. Parasitol., vol. 83, p. 575-583.

HARTMANN, PA. and MARQUES, OAV., 2005. Diet and habitat use of two sympatric species of Philodryas (Colubridae), in South Brazil. Amphibia-Reptilia, vol. 26, p. 25-31.

HEYMONS, R., 1935. Pentastomida, In H.G Bronn (ed.), Klassen und Ordnungen der Tierreichs. Leipzig, Akademische Verlagsgesellschaft. p. 1-267.

MARCOGLIESE, DJ., 2004. Parasites: small players with crucial roles in the ecological theater. Ecohealth, vol. 1, p. 151-164.

MARTINS, M. and OLIVEIRA, ME., 1999. Natural history of snakes in forests of the Manaus region, Central Amazonia, Brazil. Herp. Nat. Hist., vol. 6, no. 2, p. 78-150.

MOTTA, CS., 1963a. Considerações sobre o gênero Cephalobaena Heymons, 1922 (Linguatulida), Cephalobaena tetrapoda. Atas Soc. Biol. Rio de Janeiro, vol. 7, no. 4, p. 7-8.
-, 1963b, Considerações sobre o gênero Raillitiella Sambon, 1910. Atas Soc. Biol. Rio de Janeiro, vol. 7, no. 2, p. 8-10.

PENCE, DB. and SELCER, KW., 1988. Effects of pentastomid infection of reproduction in a southern Texas population of Mediterranean gecko, Hemidactylus turcicus, Copeia, vol. 1988, no. 3 , p. $565-572$.

REGO, AA., 1981. Notas sobre alguns pentastomídeos de répteis. Mem. Inst. Butantan, vol. 44-45, p. 233-238.

-, 1983. Pentastomídeos de répteis do Brasil: Revisão dos Cephalobaenidae. Mem. Inst. Oswaldo Cruz, vol. 78, no. 4, p. 399-411.

-, 1984. Sinopse dos pentastomídeos da região neotropical. Garcia de Orta, Série Zoologia, Lisboa, vol. 11, p. 45-46.

RILEY, J., 1986. The biology of pentastomids. Adv. Parasitol., vol. 25, p. 45-128.

RILEY, J., POWELL, R. and SMITH, DD., 1991. Further observations of blunt-hooked pentastomids belonging to the genus Raillietiella Sambon, 1910 infecting Hemidactylus brookii (Sauria: Geckonidae) in Africa and the Caribbean; comparison with closely related Raillietiella spp. from an African skink (Mabuya perrotetii). Syst. Parasitol., vol. 20, p. 47-57.

SAMBON, LW, 1922. A synopsis of the family Linguatulidae. J. Trop. Med. Hyg., vol. 25, p. 188-206.

VANZOLINI, PE., RAMOS-COSTA, AMM. and VITT, LJ., 1980. Répteis das caatingas. Academia Brasileira de Ciências, Rio de Janeiro, $161 \mathrm{p}$.

VARELA-FREIRE, AA., 1995. Levantamento entomofaunístico da Estação Ecológica do Seridó, Serra Negra do Norte, RN. Revista de Biociências, vol. 1, no. 1, p. 35-48.

-, 2002. A Caatinga Hiperxerófila Seridó, a sua caracteriuzação e Estratégias para sua Conservação. São Paulo: Academia de Ciências do Estado de São Paulo, 2002.

ZHANG, Y., ZHANG, S., LI, K., CHEN, H. and XIE, H., 1988. Reports of pentastomiasis in Gekko gecko in China. J. Guangxi Agr. College, vol. 7, p. 61-64.

ZAR, JH., 1999. Biostatistical Analysis. $4^{\text {th }}$ ed. Upper Saddle River: Prentice-Hall, 663 p. 
